\title{
BATIK GARUT: Studi Tentang Sistem Produksi dan Pemasaran
}

\author{
Oleh Irvan Setiawan
}

\author{
Balai Pelestarian Sejarah dan Nilai Tradisional Bandung \\ Jln. Cinambo No. 136 Ujungberung Bandung \\ Email: kamaliasetiawan@yahoo.co.id
}

\begin{abstract}
Naskah diterima: 30 Juni $2010 \quad$ Naskah disetujui: 6 September 2010
Abstrak

Batik Garut atau yang lebih dikenal dengan nama batik Garutan, saat ini sudah menampakkan kiprahnya dalam kancah dunia perbatikan Indonesia. Upaya untuk berkiprah ini tidak luput dari beberapa persiapan yang harus dilakukan, terutama dalam sistem produksi dan sistem pemasaran agar dapat bersaing baik dengan motif batik dari daerah lain, baik dari segi kualitas maupun kuantitas. Oleh karena itu, penelitian yang menggunakan metode deskripsi dengan pendekatan kualitatif ini ingin mengungkapkan dua hal tersebut di atas. Hasil penelitian menunjukkan bahwa meski masih menggunakan sistem manajemen keluarga namun dalam hal sistem produksi yang dilakukan mulai menunjukkan adanya unsur teknologi modern di samping teknologi tradisional yang digunakan untuk mendukung pesanan dalam jumlah banyak. Sistem pemasaran juga sudah mulai menampakkan perubahan dari sistem lama yang hanya menggunakan keahlian berkomunikasi, kini telah mengalami peningkatan terutama dari segi promosi baik dengan menggunakan media elektronik (promosi dengan menggunakan internet) ataupun keikutsertaan dalam berbagai macam pameran dan pergelaran busana.
\end{abstract}

Kata kunci: batik Garut, produksi, pemasaran.

\section{Abstract}

Batik Garut, or popularly called batik garutan is becoming a more significant asset in the world of batin in Indonesia nowadays. Efforts such as production and marketing system should be into consideration in order to make batik garutan worth competing with batiks of other regions in Indonesia, especially in terms of quality and quantity. These issues were examined in this research, and the author conducted a descriptive method as well as qualitative approach.The result indicates that, although the industries are still applying family management system, modern technology has been adopted without leaving the old and traditional one. In fulfilling great amount of market demands, old marketing system is improved by implementing an online marketing tekchnique as well as participating in fashion shows and other exhibiton events.

Keywords: batik Garut, production, marketing. 


\section{A. PENDAhuluan}

Batik Indonesia yang sangat terkenal oleh masyarakat dunia mengundang banyak decak kagum akan keunikan motif dan cara pembuatan. Tidak hanya mengagumi saja, bahkan ada pula negara yang "sirik" untuk kemudian menganggap bahwa batik adalah khas dari negara tersebut. Negara yang dimaksud tidak lain adalah Malaysia. Tidak hanya batik saja ${ }^{1}$ yang apabila diinventarisir telah mencaplok sekitar 21 buah keunikan khas dan asli Indonesia.

Muncul kembali batik sebagai trend pakaian masyarakat Indonesia tentu terkait dengan pemakaian beberapa motif-motif batik yang sudah sangat dikenal yaitu "batik Jawa". Ketenaran batik dari daerah Jawa, terutama Solo dan Yogyakarta, memang sudah diakui berbagai kalangan. Apalagi dua daerah tersebut (Solo dan Yogyakarta) sampai saat ini masih dianggap sebagai pusat atau kiblat seni batik tradisional yang tetap mempertahankan konvensi seni batik.

Jawa Barat sebenarnya memiliki cukup banyak sentra-sentra batik yang tidak kalah menarik dibandingkan dengan batik dari daerah lain. Sebut saja batik Ciamis, Tasikmalaya, Cirebon, Indramayu, dan Garut, merupakan sentra batik yang telah lama dikenal masyarakat Jawa Barat.

Kendala promosi dan pengetahuan tentang manajemen pemasaran yang kurang membuat beberapa sentra batik non Solo dan Yogyakarta agak kesulitan dalam memasarkan batik khas

1 Jenis batik yang dianggap sebagai milik Malaysia adalah dari batik dengan motif parang. daerah mereka ke daerah lain. Demikian pula halnya dengan batik khas Garut atau yang lebih dikenal dengan istilah batik "Garutan". Kegiatan dan usaha pembatikan di Garut merupakan warisan nenek moyang yang berlangsung turun temurun dan telah berkembang lama sebelum masa kemerdekaan. Pada tahun 1945 Batik Garut semakin popular dengan sebutan Batik Tulis Garutan. Berdasarkan data Dinas Perindustrian dan Perdagangan Kabupaten Garut tahun 2006, batik Garut pernah mengalami masa jaya yaitu antara tahun 1967 s.d. 1985 (126 unit usaha). Saat ini usaha pembatikan di Garut sedikit demi sedikit sudah mulai menunjukkan penurunan produksi. Penyebabnya tentu bukan disebabkan sepi order tetapi juga kelangkaan pekerja akibat proses regenerasi yang kurang berjalan lancar. Saat ini sebagian besar pekerja sudah berusia lanjut, sedangkan pekerja muda sangat sedikit. Kalangan generasi muda tentu cenderung memilih pekerjaan yang bersifat instan serta tidak akan lama bertahan dengan pola kerja yang menuntut ketelitian tinggi. Apalagi ditambah dengan tingkat upah yang minim. Berdasarkan catatan Pemda Kota Garut, dari semula tiga industri batik Garut saat ini hanya tinggal satu yang tetap berproduksi.

Persaingan dalam dunia bisnis secara umum adalah hal yang lumrah. Jatuh atau bangkrutnya jenis produk tertentu tentu akan diisi dengan jenis produk yang sama namun dalam kemasan dan promosi yang lebih menarik pembeli. Akan sangat berbeda halnya apabila jenis produk tersebut adalah salah satu warisan budaya yang 
menjadi maskot sebuah daerah. Pengusaha yang memasarkan salah satu jenis produk budaya lebih cenderung hanya menjalankan sebuah bisnis berdasarkan perhitungan untung rugi saja. Sementara itu, nilai immateriil sebuah produk budaya kurang begitu diperhatikan. Padahal, dari sisi immateriil tersebut dapat menjadi nilai tambah yang dapat menaikkan nilai /status sebuah produk budaya. Alhasil, meski kemasan dan mutu sebuah produk sangat bagus namun apabila tidak disertai dengan promosi tentang khasiat atau makna yang terkandung dalam jenis produk tersebut maka bukan tidak mungkin produk tersebut hanya akan menjadi penghias etalase saja.

Batik Garutan saat ini sedang menghadapi kendala penurunan jumlah produksi. Permasalahan klasik, yaitu pemasaran yang mulai menyusut, adalah ujung dari semua masalah yang dihadapi pengusaha batik Garut. Melalui penelitian ini akan ditelusuri kendala yang dihadapi pengusaha batik Garut berdasarkan pendekatan kebudayaan. Segi yang akan dikaji adalah sistem produksi dan sistem pemasaran agar dapat bersaing baik dengan motif batik dari daerah lain, baik dari segi kualitas maupun kuantitas. Selain itu, akan ditelusuri juga sistem manajemen yang digunakan untuk mengelola sebuah produksi.

Beberapa konsep yang digunakan sebagai kerangka pemikiran untuk meneliti tentang batik berkisar tentang definisi batik, etos kerja, dan sistem pemasaran.

Dalam Kamus Besar Bahasa Indonesia menyebutkan bahwa batik adalah kain bergambar yang pembuatannya secara khusus dengan menu- liskan atau menerapkan malam pada kain itu, kemudian pengolahannya diproses dengan cara tertentu. Dengan kata lain, batik merupakan seni gambar di atas kain yang dibuat dengan teknik resist menggunakan material lilin. Kata batik itu sendiri berasal dari bahasa Jawa yang berarti menulis. Jika melihat pengertiannya, dapat dibayangkan bahwa batik merupakan sebuah kain atau produk sandang yang bernilai spesial.

Berdasarkan wilayah persebarannya, secara umum sentra kerajinan batik dapat dibagi dua, yaitu batik pedalaman dan batik pesisiran (FraserLu, 1986: 58-74). Sentra industri batik pedalaman yang dikenal, antara lain Yogyakarta, Surakarta, Tasikmalaya, Garut dan Ciamis, serta Banyumas. Selain itu masih dikenal pula sentra kerajinan batik yang termasuk pedalaman, yaitu Bayat (Klaten), Wonogiri, Bantul, Purworejo, dan Pacitan. Adapun yang termasuk sentra batik pesisiran adalah Cirebon, Tegal, Pekalongan, Semarang, Kudus, Juana, Lasem, Tuban, Gresik, Sidoarjo, dan Pulau Madura.

Kedua sentra industri batik (pedalaman dan pesisir) masing-masing memiliki ciri khas. Walaupun demikian, ada beberapa bentuk kesamaan terutama dari segi pemakaian. Batik yang dipergunakan perempuan rata-rata memiliki perbedaan motif dengan batik yang dipergunakan laki-laki. Hal ini terungkap dari pemikiran Fakih terkait dengan konsep perbedaan gender yang secara umum berlaku bagi produk seni budaya pada suku bangsa Indonesia. Secara jelas Fakih mengungkapkan bahwa penciptaan karya seni, sebagai salah satu wujud hasil proses budaya, 
dimiliki hampir semua suku bangsa yang ada di Indonesia. Secara naluriah, penciptaan karya seni itu kadangkadang menampakkan pembedaan kewenangan antara pria dan wanita sehingga mengakibatkan pula perbedaan kepemilikan di antara mereka. Pembedaan seperti itu ternyata lebih dapat dikatakan sebagai akibat sistem sosial budaya daripada didasarkan pada kemampuan yang dimiliki oleh seseorang (Fakih, 1997: 8).

Tidak hanya berpijak dari produk budaya saja, masalah tentang perbedaan gender juga dikaitkan dengan perbedaan etos kerja antara laki-laki dengan perempuan. Perempuan lebih mengutamakan keuletan dalam melakukan pekerjaan sementara laki-laki tidak akan sanggup menandingi keuletan atau bahkan kesabaran perempuan dalam bekerja. ${ }^{2}$

Sebenarnya etos kerja tidak melulu hanya didasarkan atas perbedaan gender semata. Secara sederhana kata etos, dapat didefinisikan sebagai watak dasar dari suatu masyarakat. Perwujudan etos itu dapat dilihat dari struktur dan norma sosial masyarakat itu. Sebagai watak dasar dari masyarakat, etos menjadi landasan bagi perilaku diri sendiri dan lingkungan sekitarnya, yang terpencar dalam kehidupan masyarakat. Oleh karena etos menjadi landasan bagi kehidupan manusia, maka etos itu juga berhubungan dengan aspek evaluatif yang bersifat menilai dalam kehidupan masyarakat (Sairin, 2002). Penurunan etos kerja secara tidak langsung

${ }^{2}$ Hal ini juga dilakukan sama oleh perusahaan rokok yang banyak memperkerjakan pekerja perempuan karena tingkat keuletan mereka lebih tinggi daripada pekerja laki-laki. menjadi salah satu penyebab dari penurunan produksi.

\section{B. HASIL DAN BAHASAN}

\section{Tenaga Kerja}

Saat ini jumlah pekerja batik tulis di Kabupaten Garut tidak lebih dari 100 orang. Tenaga ini kemudian terbagi 2 bagian yaitu pelukis dan pemberi warna. Jumlah pelukis batik biasanya lebih sedikit dibandingkan dengan bagian pemberi warna. Hal ini dapat disadari karena tidak banyak orang yang mengetahui motif-motif batik. Di samping memerlukan proses pembelajaran yang cukup lama, bakat melukis juga menjadi faktor dominan. Bakat yang dapat disamakan sebagai hobi mencegah seorang pelajar untuk berpindah pekerjaan karena ia memang menyukai untuk melukis batik. Seorang yang sangat pandai dalam pengetahuan motif batik namun apabila tidak didampingi dengan hobi cenderung untuk berpindah pekerjaan. Apalagi faktor jenis pekerjaan "membatik" dianggap sudah ketinggalan zaman, sementara di depan mata jelas terlihat berbagai jenis pekerjaan yang dianggap lebih "bonafide" pada saat ini telah menjadi kendala sangat besar bagi kelangsungan generasi penerus pelukis batik. Dan, sedikit demi sedikit jelas terlihat penurunan drastis jumlah pelukis batik tulis Garut. Untuk saat ini saja, seorang pengusaha batik tulis mengungkapkan bahwa sangat sulit mencari pelukis batik Garut. Melani (45), Asisten Manajer Batik Garutan "RM"3 mengatakan bahwa "Jumlah

${ }^{3}$ Lihat "Batik Garutan Krisis: Perajin Batik Trusmi Terhadang Modal", dalam http://batiksastro.wordpress.com/2006/04/04/ba 
tenaga pelukis motif yang kami miliki sangatlah terbatas, hanya 10 orang dari total 46 pekerja “. Padahal ia sangat memerlukan tambahan tenaga pelukis batik Garut untuk mengimbangi tenaga pewarna lukis yang jumlahnya lebih banyak.

Seperti pada umumnya usaha pembatikan lain di Jawa, para pengrajin di Garut pun umumnya kaum wanita. Pekerjaan membatik selain membutuhkan ketelitian tinggi juga mesti didasari cita rasa seni yang memadai. Tanpa memiliki kedua aspek di atas rasanya agak mustahil menjadi perajin batik tulis. Dengan berbagai pertimbangan tersebut maka pilihan tenaga kerja wanita merupakan sebuah pilihan yang tepat. Kenyataan ini sebelumnya telah disanggah oleh Dwiyanto dan Nugrahani, (2000: 12) yang mengatakan bahwa adalah salah apabila ada anggapan bahwa laki-laki tidak pantas ditempatkan dalam bidang perbatikan karena berdasarkan hasil pengamatan menunjukkan bahwa pembatik laki-laki memiliki kualitas yang seimbang dengan pembatik perempuan. Jadi perihal membatik tidak dapat dikaitkan dengan konsep gender. Iwan Tirta, Peter Sie, Amri Yahya, Sapto Hudoyo adalah beberapa contoh pembatik lakilaki yang dapat dikatagorikan cukup sukses. Sebenarnya contoh yang disebutkan oleh Dwiyanto dan Nugrahani adalah pengusaha batik, dan bukan seorang pembatik.

Semua Pengusaha batik Garutan adalah perempuan, karena perempuan dikenal tekun, pandai memanfaatkan waktu luang dan kesempatan, gigih

tik-garutan-krisis-perajin-batik-trusmi-ter hadang-modal/ berusaha untuk menambah pendapatan keluarga, pandai dalam pengelolaan keuangan, pemasaran dan pengelolaan perusahaan kecil yang bersifat rumah tangga. Walaupun demikian tidak menutup kemungkinan bahwa laki-laki di Kecamatan Garut Kota dapat berpartisipasi dan ikut bekerja sebagai pembatik meskipun bukan sebagai pengusaha, melainkan sebagai bekerja dalam berbagai proses pembatikan, mulai dari taraf memotong bahan baku, ngawarnaan, hingga bidang penjualan.

Beberapa pekerja wanita memilih mengerjakan proses membatik di rumah masing-masing sehingga mereka masih bisa melaksanakan pekerjaan rutin rumah tangganya. Mereka disebut pekerja borongan dan setelah rampung pekerjaan tersebut disetorkan kepada pemilik perusahaan. Seorang perajin batik tulis "rumahan" rata-rata mampu menyelesaikan 1 potong kain ukuran 110 x $260 \mathrm{~cm}$. Sedangkan untuk pengerjaan batik cap dalam 1 minggu dapat dihasilkan 3 kodi atau 60 helai. Mereka hanya mendapat upah kerja, mengenai kebutuhan bahan seperti kain, malam dan canting seluruhnya disediakan pihak pengusaha.

Cara pengupahan dilakukan dengan sistem borongan sesuai dengan tingkat kesulitan motif maupun jenis bahannya. Bahan dari ATBM (Alat Tenun Bukan Mesin) dinilai pengerjaannya lebih sulit dibanding bahan lainnya. Dengan sendirinya upahnya pun lebih mahal. Sedangkan upah batik cap lebih murah namun jumlah pesanannya lebih banyak. Biasanya bahan tersebut untuk keperluan seragam. 


\section{Proses Pembelajaran Pembuatan Batik Garut}

Pembatik yang menggunakan cap, dapat dikatakan tidak dituntut mempunyai keahlian seperti pada pembuatan batik tulis. Berbeda dengan para pembatik tulis yang dituntut mempunyai standar keahlian untuk menghasilkan sehelai batik halus. Keahlian tersebut tidak dapat dicapai seketika. Seringkali seorang pembatik harus melampaui beberapa tingkatan agar dipercaya untuk membuat batik tulis yang halus. Dari sejumlah responden yang diwawancarai, diketahui terdapat beberapa kelas pembatik. Pembatik kelas pertama adalah kelompok mahir, yang mengerjakan batik tulis di atas kain sutera tanpa menggunakan gambar pola yang dibuat dengan pensil. Pada umumnya para pembatik kelas ini telah mempunyai pengalaman puluhan tahun. Pembatik kelas kedua adalah mereka yang bekerja sesuai dengan spesialisasinya, misalnya hanya mengerjakan proses nglowongi, nemboki, neuruskeun, atau membuat isenan saja. Selain itu, masih terdapat kelas pembatik yang masih harus menggunakan pola, sehingga mereka memerlukan mori yang sudah diberi pola terlebih dahulu. Pembatik kelas ini dapat dikatagorikan sebagai pemula. Pada umumnya mereka mengerjakan motif-motif yang mempunyai tingkat kesulitan rendah. Desain motif batik biasanya digambar dengan pensil secara keseluruhan di atas mori.

Pola pembelajaran pembuatan batik Garutan bukanlah diibaratkan sebagai seorang guru dan murid dalam sebuah kelas formal. Sangat jauh berbeda dengan bayangan tersebut, karena apa yang diperoleh dari seorang pembatik Garutan sebagian besar diajarkan secara turun temurun dan itupun melalui proses trial and error tanpa diiringi dengan keterikatan waktu dan tempat. Bakat serta hobi adalah faktor penentu dalam proses pembelajaran membatik, mengingat batik adalah sebuah seni yang membutuhkan konsentrasi serta imajinasi tinggi agar apa yang dihasilkan dapat sesuai dengan pola, aturan, pakem, dan cocok dengan selera pembeli/pengguna.

Perihal proses pembelajaran secara turun temurun mulanya disertai dengan embel-embel status keningratan seseorang. Hal ini terungkap dari ungkapan informan sekaligus sebagai pengusaha batik Garutan dengan merk "TULEN" bernama ibu Odah. Beliau memaparkan bahwa usaha batik tulis yang ditekuninya adalah usaha turun temurun dalam keluarganya sejak nenek buyut yang sangat terkait pakem tradisional atau mengikuti aturan tertentu (pengaruh faktor sosial dan budaya). Aturan itu antara lain :

- Seorang perempuan bisa membuat batik tulis hanya berasal dari keluarga bangsawan atau keluarga yang memang biasa membuat batik.

- Seorang penulis batik baru diperbolehkan membuat batik tulis kalau sudah mendapat predikat "Ayu", yaitu sudah dinilai lulus dari sekolah batik yang diikutinya.

Tenaga muda pembatik tersebut biasanya masih berasal dari lingkungan keluarga yang juga intens menjadi pembatik tulis. Kendalanya, kadang pembatik muda masih memiliki anak kecil. Tidak jarang pengerjaan batik tulis agak terbengkalai sehingga yang 
seharusnya bisa dikerjakan dalam dua bulan akhirnya "molor" (tidak tepat waktu).

\section{Tahap Pembuatan Batik Garut}

Setelah bahan baku dan peralatan telah disiapkan terlebih dahulu, proses pengerjaan membatik dapat segera dilaksanakan. Dapat dikatakan bahwa tahap pembuatan batik tulis memerlukan ketekunan, ketelitian, dan keahlian yang cukup tinggi. Ketekunan, dan ketelitian sangat diperlukan mengingat waktu pengerjaan batik tulis Garutan relatif lama. Selembar kain batik tulis baru dapat diselesaikan sekitar satu hingga 1,5 hingga 2 bulan. Sementara keahlian dibutuhkan dalam penuangan goresan canting berisi malam di atas media kain. Sedikit saja melenceng dapat mengakibatkan penurunan harga jual batik tulis yang dikerjakannya.

\section{a. Pemotongan bahan baku}

Proses pertama ini dilakukan dengan mempertimbangkan kegunaan selanjutnya dari pembeli. Para pengusaha batik memprediksi kegunaan kain batik yang terbagi menjadi beberapa kebutuhan, apakah akan dibuat kebaya, sinjang (biasanya berukuran 110 x $260 \mathrm{~cm}$ ), sarung, dan lain-lain. Khusus untuk batik printing tentu diproduksi dalam skala besar karena proses pengerjaan yang sangat cepat. Dan, untuk hal tersebut, tidak begitu berpengaruh proses pertama ini. Biasanya proses pemotongan dilakukan pada proses terakhir setelah pengecapan.

\section{b. Ngateli}

Proses ini ialah proses pemasakan kain sebelum dilakukan proses pewarnaan. Proses ini dilakukan dengan cara penyabunan dalam alkali. Zat kimia yang dipergunakan dalam proses ini ialah $\mathrm{KCO} 2$ (air abu merang), $\mathrm{NaCO} 2$ (soda abu), $\mathrm{NaOH}$ (kostik soda). Bahan lainnya yang dipergunakan ialah minyak kacang, minyak jarak, minyak nyamplung, dan minyak klenteng.

Setelah proses selesai, mori lalu diuleni hingga merata dan kemudian dijemur sampai kering. Setelah kering proses uleni dilanjutkan kembali dan kain kemudian dijemur lagi. Proses ini dilakukan berulang-ulang sampai tiga minggu lamanya, lalu dicuci sampai bersih. Tujuan dari pemasakan ialah untuk menghilangkan zat-zat kimiawi yang menempel pada serat. Selain itu, agar zat warna bisa meresap ke dalam serat kain dengan sempurna.

\section{c. Penganjian}

Penganjian dilakukan dengan tujuan untuk menjaga agar susunan benang pada kain tetap stabil dan menjaga agar malam tidak dapat menembus serat benang sehingga mudah dalam proses melorod. Penganjian ini dilakukan dengan mempergunakan larutan kanji cair.

\section{d. Ngemplong}

Proses ngemplong dilakukan dengan tujuan untuk menghaluskan permukaan kain, sehingga kain tersebut memiliki permukaan yang rata. Permukaan kain yang rata sangat dibutuhkan untuk mempermudah proses pemalaman dan pewarnaan. Proses ini dilakukan dengan cara sebagai berikut: kain yang akan dibatik dilipat sebanyak enam belas (16) lipatan kemudian kain tersebut dipukuli dengan mempergunakan pemukul kayu 
dan sebagai alasnya dipergunakan sebilah kayu yang permukaannya licin.

Proses pewarnaan pada batik dilakukan dengan cara celup dingin, dan proses pewarnaan tersebut dapat dilakukan dengan dua cara, yaitu dicelup dan dicolet. Proses pencelupan pada batik dibagi dalam beberapa tahapan sesuai dengan jenis zat warna yang harus digunakan. Sementara itu, proses pencoletan yaitu proses pemberian warna pada bagian-bagian dari corak atau motif yang berukuran kecil dengan mempergunakan kuas yang terbuat dari bambu.

\section{e. Ngarengreng}

Ngarengreng, adalah salah satu proses menggambar pada sebuah kain. Kain itu sendiri sudah diberi pola atau batas dan diukur. Mereka menyebutnya sudah "dijidaran". Jadi perajin tinggal melukisnya dengan malam menggunakan alat canting mengikuti pola kasar tersebut. Tampaknya untuk melukis motif atau ragam hias pengisi bidangbidang kosong atau garis-garis tidak perlu lagi diberi pola, mereka otomatis sudah hafal betul. Fungsi ngajidaran adalah untuk menempatkan motif secara garis besarnya saja. Setelah proses pertama selesai selanjutnya proses nerusan atau neruskeun.

\section{f. Ngabiron}

Ngabiron yaitu menutupi kedua bidang permukaan kain dengan malam agar tidak ada bidang yang masih terbuka atau salah tutup. Proses di atas dilakukan sebelum pencelupan warna. Proses ngabiron sehelai batik berlangsung sekitar 1 minggu. Kain yang sudah dibiron tersebut kemudian ditimbang beratnya untuk mengetahui bahan malam yang sudah digunakan.
Rata-rata bahan "malam" (semacam cairan lilin) yang diperlukan ngabiron sehelai kain kurang lebih 1 sampai 1 $1 / 4 \mathrm{~kg}$.

\section{g. Ngawarnaan}

Proses pewarnaan dilakukan dengan cara mencelupkan pada warna tertentu. Bidang kain yang terbuka atau tidak tertutup oleh malam tersebut yang akan diberi warna. Dalam proses batik warna tertentu dihasilkan darimisalnya untuk warna hijau pencelupan warna biru dan kuning. Demikian pula untuk warna coklat, soga, gading dan beberapa warna lainnya terbuat dari warna campuran yang memerlukan dua tiga kali proses pencelupan.

Pada masa dahulu persaingan di kalangan pembatik Garutan, dan juga jenis batik daerah lain tergolong ketat karena hanya batik yang menjadi simbol keelitan/keningratan sang pemakai. Warna menjadi bagian dalam pola persaingan dan harus terjaga kerahasiaan agar tidak dapat ditiru dalam proses pencampuran berbagai bahan pewarna - yang pada saat itu masih menggunakan bahan alami.

Dalam hal penggunaan warna, para pembatik menggunakan pewarna alami dari jenis tanaman indigo tinctoria, peltthophorium ferrrugeneum, morinda citrofolia, symploco fascicula, dan sophora joponica (Frasser-Lu, 1986: 17-18). ${ }^{4}$ Sedikit demi sedikit persaingan dalam hal bahan pewarna mulai berkurang

\footnotetext{
${ }^{4}$ Berbeda halnya bahan batik Jakarta Pada masa dahulu, bahan-bahan baku batik yang dipergunakan ialah hasil tenunan sendiri dan obat-obatnya hasil ramuan sendiri dari bahanbahan kayu mengkudu, pace, kunyit, dan sebagainya.
} 
karena alasan kepraktisan. Dan, saat ini sudah tidak ada lagi persaingan tersebut karena seluruh pembatik Garutan telah menggunakan bahan kimia dari pabrik. Warna sintetis/buatan pabrik harus didatangkan dari negara-negara yang mampu memproduksi pewarna kain. Beberapa di antaranya yaitu Jerman menghasilkan pewarna merek HOECHST, Inggris merek ICI, Swiss merek CIBA. Merek FRANCOLOR diproduksi di Perancis, DU PONT di USA, dan ACNA di Italia.

\section{h. Ngarorod}

Ngarorod adalah upaya menghilangkan malam tersebut dari kain. proses ngarorod dengan cara direbus di sebuah tungku. Proses membuka dan menutup malam tersebut berulangkali dilakukan sesuai dengan jumlah warna yang diinginkan.

Penghilangan malam tersebut dilakukan dengan cara merebus kain dalam air mendidih. Selain dengan cara ngarorod, proses penghilangan malam juga dapat dilakukan dengan cara dikerok. Pengerokan inipun dilakukan ketika kain berada dalam rebusan air mendidih. Sebelum dilakukan pengerokan kain harus dilrendam dulu supaya kanji yang melapisi kain tersebut menjadi lunak, dengan demikian proses pengerokan akan menjadi mudah.

Setelah seluruh proses tersebut di atas selesai, proses pengerjaan batik ini kemudian diakhiri melalui tiga proses, yaitu: proses pemberian kanji, nguwuk, dan melipat kain.

Proses pemberian kanji dilakukan setelah seluruh malam yang menempel pada kain telah berhasil dihilangkan, sedangkan kekentalan kanji yang dipergunakan disesuaikan dengan jenis kain morinya. Kain mori yang kasar, seperti blacu, memerlukan kanji yang kental. Setelah proses pemberian kanji selesai maka kain batik tersebut dijemur hingga kering.

Nguwuk. Proses ini dilakukan dengan tujuan untuk menjadikan permukaan kain batik tersebut mengkilat. Caranya ialah dengan menggosokkan benda halus ke atas seluruh permukaan kain batik yang telah selesai dikanji tadi. Dalam proses penggosokan itu dapat pula diberikan lapisan parafin. Proses nguwuk biasanya dilakukan pada kain batik yang terbuat dari kain mori yang kasar.

Melipat Kain. Tahap terakhir yang dilakukan ialah melipat kain-kain batik tersebut. Pelipatan ini dilakukan dengan tujuan untuk memudahkan dalam penyimpanan dan transportasi.

\section{Eksistensi Motif Batik Garut di Tengah Dunia Perbatikan Indonesia}

Batik Garut, sama halnya dengan produk benda budaya lainnya, tidak hanya menjadi hak milik masyarakat Garut semata tetapi turut menjadi hak milik budaya dan masyarakat Indonesia. Istilah batik itu sendiri bersifat nasional yang selalu menjadi kata depan dari setiap produk spesifik "kain bergambar" dari tiap wilayah administratif/budaya di Indonesia. Motif batik itu sendiri sudah mencerminkan akulturasi antara wilayah budaya satu dengan wilayah budaya lainnya di Indonesia. Batik Garut dengan kekentalan motif sundanya, ternyata sudah berakulturasi batik dari wilayah Jawa (terutama Jawa Tengah dan Yogyakarta). Bedanya, para pembatik Jawa kerap masih memegang pakem dari kesultanan 
(Surakarta dan Yogya) sehingga setiap motif disesuaikan menurut tingkatan atau golongan, seperti batik motif kesultanan berbeda dengan batik yang biasa dipakai masyarakat umum. Sangat jarang ada yang melanggar dengan cara mencampuradukkan motif "kelas bawah" dengan motif "kelas atas". Perilaku pembatik motif Jawa secara tidak langsung mencerminkan keteguhan masyarakat Jawa hingga saat ini dalam melihat perbedaan status antara masyarakat biasa dengan wilayah kesultanan.

Batik Yogya misalnya, batikbatik dari daerah ini tampak masih konsisten pada motif-motif tradisional. Banyak yang mengakui, itu memang menjadi kekuatan batik Yogya. Misalnya dengan motif-motif sogan, paduan warna hitam, kuning, dan putih. Lain halnya dengan batik Surakarta (Solo), meskipun ada tata letaknya yang berubah namun motifnya tetap. Untuk motif, batik Solo cenderung mempertahankan tradisi, misalnya pada motif lereng. Lereng yang dipakai keluarga keraton adalah lereng yang besarnya lebih dari $10 \mathrm{~cm}$. Lereng Barong yang lebih besar digunakan oleh golongan Sultan. Tapi, di bawahnya (kerabat Sultan) lebih kecil lagi. Polanya tetap antara lain terkenal dengan "Sidomukti" dan "Sidoluruh".

Pada masa kekinian, keteguhan untuk menerapkan motif pada status tertentu mulai bergeser. Hal ini diungkapkan oleh Riswinarno (tt: 17) bahwa, awalnya batik dikerjakan terbatas di lingkungan kraton saja dan hasilnya untuk pakaian raja dan keluarga serta para pengikutnya. Oleh karena banyak dari pengikut raja yang tinggal di luar keraton, maka kesenian batik ini dibawa oleh mereka keluar keraton dan dibuat di tempat mereka tinggal. Sejalan dengan waktu, batik kemudian ditiru oleh rakyat terdekat dan selanjutnya meluas menjadi pekerjaan kaum wanita untuk mengisi waktu senggang.

Batik Sunda dengan motif yang nampak sepintas berbeda dengan batik Jawa namun memiliki beberapa karakteristik yang sama dengan batik Jawa. Hal tersebut dapat dimaklumi karena karakteristik urang Sunda relatif lebih terbuka dibandingkan dengan masyarakat Jawa. Hal ini tentu dapat langsung diterka setelah melihat masih adanya sisa-sisa kejayaan yang hingga kini utuh berada di lingkungan keraton Surakarta dan Ngayogyakarta sehingga secara tidak langsung masih memancarkan kharisma keagungan keraton. Berbeda dengan masyarakat Sunda yang saat ini tidak menyisakan sedikit pun sisa-sisa bangunan kerajaan Pajajaran. Kerajaan Galuh yang saat ini masuk dalam wilayah administratif Kabupaten Garut, juga tidak menyisakan fisik bangunan dan bahkan kharisma kerajaan dapat dikatakan sudah punah dalam pandangan mata masyarakat Garut. Dua, atau bahkan lebih, jumlah kerajaan di wilayah Tatar Sunda saat ini sudah tidak ada bekas sama sekali secara psikis mempengaruhi pola pikir urang Sunda untuk tidak terpaku pada satu sosok pembesar atau petinggi, melainkan selalu berpikir terbuka untuk menemukan ide atau bentuk-bentuk baru yang dianggap dapat memberi kehidupan yang lebih baik, namun tetap memegang teguh etika kesundaan dengan slogan lemah cai (sunda: tanah air). 
Sebenarnya tidak hanya batik saja yang selalu menelurkan ide-ide pembaharuan, tetapi banyak kesenian Sunda yang terus berupaya untuk memodifikasi waditra ataupun kesenian secara keseluruhan agar terus mendapat respon masyarakat. Sebut saja seni sastra, tembang kecapi suling, tari, wayang golek, sandiwara, batik tulis serta tata-cara berpakaian. Lakon wayang umpamanya, tidak lagi utuh dipertunjukkan di depan umum sebagaimana asalnya, melainkan telah mendapat improvisasi Ki Dalang sesuai dengan masa dan masyarakat penikmatnya. Demikian juga dengan bentuk -bentuk seni lainnya telah mendapat pengembangan daya cipta berdasarkan imajinasi para senimannya tanpa beranjak dari akarnya sendiri. Penampilannya disesuaikan dengan lingkungan kondisi masyarakat penerima serta zamannya.

Ciri-ciri dasar batik Garut yang sama dengan batik Sunda secara keseluruhan mencerminkan dinamika urang Sunda untuk berimprovisasi dalam suasana keceriaan dan keindahan alam Tatar Sunda. Bukan hanya masa kini keceriaan tersebut muncul. Berdasarkan buku Kidung Sunda yang diterbitkan pada tahun 1928 oleh Bale Poestaka di Weltevreden, Batavia, dilukiskan bahwa warna yang dipilih sudah tergambar dengan sendirinya dan tersusun dalam urutan warna merah, yaitu:

1. beureum (merah)

2. beureum cabe (merah cabe)

3. beureum ati (merah hati)

4. kasumba (merah ketela pohon)

5. kayas (merah mawar)

6. gedang asak (merah pepaya masak)

7. gading (kuning gading)
8. koneng (kuning)

9. koneng enay (kuning pisang).

Sementara untuk warna biru dan hijau tersusun urutan warnanya sebagai berikut:

1. hejo (hijau)

2. hejo lukut (hijau lumut)

3. hejo ngagedod (hijau kelam)

4. hejo paul

5. paul

6. gandaria (ungu)

7. gandola (ungu kelam)

8. bulao saheab (biru sekilas)

9. pulas haseup

10. bulao (biru).

Selain warna merah, biru, dan hijau, pilihan warna urang sunda juga tertuju pada warna yang tidak terurai berdasarkan tingkat kekelaman. Beberapa warna yang dimaksud, yaitu:

1. bodas

2. hideung

3. borontok

4. coklat kopi atau pulas kopi, kopi tutung

5. candra mawat

6. bulu hiris

7. bulu oa : dawuk, hawuk, kulawu, pulas lebu

Dari beberapa warna tertera di atas, secara keseluruhan batik Garut menganut konsep serupa. Motif-motif yang dipergunakan pada batik Garut mengambil pola bentuk-bentuk flora dan fauna. Sementara warna yang digunakan dalam batik Garutan umumnya warna cerah, seperti krem, merah, hijau, dan kuning.

5 (oa adalah sebangsa primata / monyet berbulu warna abu-abu) 
Keseluruhan warna yang menjadi pedoman dalam pembuatan batik berikut tata cara berbusana orang Sunda berpedoman pada komposisi motif dan jenis busana yang dikenakan. Hal ini disebabkan ada unsur simbolik dan artistik yang menaungi setiap busana yang akan dikenakan. Tidak lupa untuk memilih dua unsur warna yang digunakan, yaitu warna dari tumbuh-tumbuhan (celup alam) dan warna kimia (buatan). Dua unsur warna ini sangat berpengaruh terhadap pembuatan pola corak pembuatan batik, mengingat ada motif-motif tertentu yang harus menggunakan warna tertentu pula.

Kecenderungan masih dipergunakan beberapa pedoman dalam pembuatan batik Garut tentu tidak didasarkan atas adanya perbedaan kelas pengguna, melainkan bersumber dari unsur sejarah, seni, pupuh, sastra, dan tembang yang memunculkan unsur simbolik seperti tertera di atas. Unsur artistik tentu bersifat subjektif dan dilihat dari kacamata masyarakat Garut itu sendiri. Apakah menarik atau tidak untuk diterapkan menjadi salah satu motif batik Garutan.

Khusus inspirasi pembuatan batik Garut dari sumber seni, pupuh, sastra, dan tembang kadang diterjemahkan secara berbeda dalam pembuatan motif batik Garut, namun secara garis besar ada kesamaan dalam pola garis dan warna yang dipergunakan. Hal ini patut dimaklumi mengingat antara satu pupuh dengan pupuh yang lain dalam menggambarkan satu objek terkadang dituangkan dalam beberapa kalimat yang berbeda namun bermaksud sama. Hal senada juga dituangkan dalam tata cara berbusana yang diungkapkan dalam berbagai sumber seni, pupuh, sastra, dan tembang Sunda. Salah satunya adalah sajak pupuh Sunda yang dinyanyikan dalam seni Celempungan atau Gamelan dari Juru Kawih H. Idjah Hadidjah, produksi Jugala tahun 1981 Bandung berjudul Kuwung-kuwung.

Syair tersebut menggambarkan keindahan alam Parahyangan yang menjadi sumber inspirasi dalam berbagai bentuk seni tembang, sastra, dan teralisasi dalam bentuk visual untuk menentukan kecocokan antara tata cara berbusana dengan alam sekitar, yaitu alam Parahyangan. Gambaran tata cara berbusana batik adat Sunda Garutan terus berlanjut melalui kemunculan syair-syair bertemakan tata cara berbusana. Salah satunya adalah Kidung Sunda yang diterbitkan pada tahun 1928 oleh Bale Poestaka di Weltevreden, Batavia, melukiskan bagaimana para bangsawan Sunda berpakaian, yang disusun dalam kinanti. Beberapa kata yang digarisbawahi dalam kinanti tersebut mengandung pengertian ragam hias, atau bahkan menjadi salah satu nama dari ragam hias yang dituangkan dalam seni batik tulis, seperti dodot, giringsing kawung, para, garuda mungkur, dan kembang bodas.

\section{a. Perwujudan Batik Garut}

Berdasarkan kondisi daerah pembatikan di Garut, dan perkembangannya, batik dengan ragam khasnya mengalami pasang surut. Sejak masa sebelum penjajahan batik Garut merupakan salah satu usaha industri rumah. Usaha pembatikan di Kabupaten Garut dianggap sebagai warisan nenek moyang yang berlangsung turun temurun. Secara umum 
teknik membatik sama dengan menulis di atas permukaan kain putih (mori) dengan alat yang disebut canting dan bahannya cairan malam. Upaya penggambaran atau memberi hiasan dalam pertekstilan dikenal dengan teknik "tutup celup" yang mirip dengan teknik celup ikat. Dalam prosesnya membatik memerlukan keterampilan, ketekunan dan kesabaran serta konsentrasi batin. Untuk menyelesaikan sehelai batik kadang-kadang memerlukan waktu berbulan-bulan, karena seluruh prosesnya dikerjakan secara manual (dengan tangan).

Dalam perkembangannya diciptakan alat cap sebagai pengganti canting yang dapat mempercepat proses pembatikan, hingga saat ini batik tulis dan batik cap berjalan berdampingan. Hasil penggambaran di atas kain melalui canting atau cap dapat dihasilkan pola-pola yang lebih bebas, halus, rumit maupun kasar bergantung desain dan bahan dasar kainnya. Sebagai bahan sandang, batik telah memenuhi fungsinya sebagai kain panjang (sinjang), selendang, sarung dan ikat kepala. Secara mendasar pada batik Garut terdapat unsur-unsur yang mempengaruhi perwujudanya seperti warna dan motif, bahan, teknis termasuk aspek psikologis dan simbolik. Adanya berbagai perpaduan unsur-unsur tersebut memberikan peluang untuk berbagai penafsiran terhadap makna yang dikandungnya.

\section{b. Makna Simbolik Batik Garut}

Secara keseluruhan batik Garut menampilkan komposisi bentuk motif dan warna yang sederhana, dan memiliki ciri khas. Gaya pembatikan pada ragam hias batik Garut dipengaruhi oleh beberapa faktor seperti letak geografis, sifat dan tata kehidupan daerah yang bersangkutan, serta keadaan alam termasuk flora dan fauna dan konstruk hubungan antardaerah pembatikan. Hal itu merupakan penampilan dari cerminan kehidupan sosial budaya dan falsafah hidup serta adat istiadat masyarakat Sunda.

Berdasarkan latar belakang sosial budaya masyarakatnya, maka perwujudan batik Garut tampak tidak begitu rumit. Hal tersebut digambarkan dengan pengulangan bentuk geometrik yang mengarah pada garis diagonal. Namun terkesan dinamis, karena diimbangi dengan penempatan warna yang serasi. Di samping itu penampilan flora digambarkan secara sederhana dengan bentuk bunga, daun dan tangkai. Hal ini dipengaruhi oleh letak geografis Kota Garut dan keadaan alam sekitarnya, termasuk bentuk fauna seperti kupu-kupu dan burung merak. Dalam hal warna sesuai dengan kondisi daerah Priangan pada umumnya yang beriklim sejuk. Dengan demikian warna latar (dasar) batik Garut berciri khas lembut/muda (kalem-Sunda), yaitu krem (gumading-Sunda) yang berdasar cerah, bersih dan dinamis.

$$
\text { Batik Garut dikenal dengan }
$$

sebutan 'Batik Garutan Asli', umumnya dibuat berupa kain sinjang yang dikenakan dalam berbagai kesempatan. Dengan perwujudan motif dan warna seperti dijelaskan di atas serta latar belakang penciptaannya, maka batik Garut tidak memiliki makna simbolik. Bahkan nama atau tema dari ragam hias diambil menurut si pemesan atau pemakai, seperti contohnya lereng dokter atau lereng camat karena yang memesan ibu dokter dan ibu camat. Kalaupun ada motif batik Garut yang memiliki makna simbolis, hanya pada 
kain panjang (sinjang) untuk upacara pengantin. Hal itu pun bersifat umum, artinya berlaku di setiap daerah pembatikan yang maknanya untuk keselamatan, kerukunan dan kelanggengan kedua mempelai. Oleh karena itu, dalam penggambaran motif dan warna batik Garut merupakan pengungkapan dari kondisi alam dan kejadian sehari-hari.

Meskipun demikian di bidang seni rupa yang menggunakan bahasa rupa dengan unsurnya seperti bentuk merupakan simbol rupa. Dalam penggunaan tertentu simbol mampu membawa energi manusia ke alam pikiran sebagai ungkapan simbolik. Dengan demikian bentuk-bentuk rupa yang terdapat pada batik Garut sebenarnya memiliki makna dan pemahaman melalui suatu penafsiran. Seperti bentuk geometrik, menurut seorang semiotik berhubungan dengan hukum atau aturan tertentu yang disebut legi sign, melambangkan pola yang tetap, teratur dan pasti. Bentukbentuk flora dan fauna dapat bermakna suatu perubahan dan pertumbuhan sebuah taman dan kehidupan suatu makhluk. Secara umum batik Garut menggunakan warna yang khas, seperti krem dan paduan dengan warna biru serta beragam warna seperti pada batik Pekalongan dan Madura. Keanekaragaman warna merupakan ciptaan Tuhan mempunyai makna untuk kepentingan manusia, yaitu daya hidup berupa sinar atau cahaya.

\section{Strategi Pemasaran}

Daerah penghasil kain batik yang paling menonjol di Indonesia ialah Pulau Jawa dengan pusat-pusatnya antara lain, Yogyakarta, Surakarta, Pekalongan, Cirebon, Tasikmalaya, dan
Garut. Salah satu penghasil batik di Jawa Barat yang cukup terkenal dan sampai saat ini masih menghasilkan kain batik yang memiliki corak dan warna yang khas adalah Garut

Kegiatan dan usaha pembatikan di Garut merupakan warisan nenek moyang yang berlangsung turun temurun dan telah berkembang lama sebelum masa kemerdekaan. Pada tahun 1945 Batik Garut semakin popular dengan sebutan Batik Tulis Garutan dan mengalami masa jaya antara tahun 1967 s.d. 1985 (126 unit usaha).

Dalam perkembangan berikutnya produksi Batik Garutan mengalami penurunan. Hal ini disebabkan oleh semakin pesatnya batik printing, kurangnya minat generasi penerus pada usaha batik tulis, ketidaktersediaan bahan dan modal, serta lemahnya strategi pemasaran.

Berdasarkan data dari Dinas

Perindustrian dan Perdagangan Kabupaten Garut sampai bulan Mei 2002, potensi industri kecil/rumah tangga (tekstil /batik) adalah sebagai berikut:

1. Industri kecil batik (formal)

$\begin{array}{ll}\text { Jumlah unit usaha } & : \text { 1 unit } \\ \text { Jumlah tenaga kerja } & : \text { 11 orang } \\ \text { Jumlah investasi } & : \text { Rp. } 4.500 .000 \\ \text { Jumlah nilai produk } & : \text { Rp. } 45.000 .000 \\ \text { Jumlah nilai bahan baku } & : \text { Rp. } 5.700 .000 \\ \text { Industri kecil batik (non formal) } & \\ \text { Jumlah unit usaha } & : \text { 2 unit } \\ \text { Jumlah tenaga kerja } & : \text { 25 orang } \\ \text { Jumlah investasi } & : \text { Rp. } 10.000 .000 \\ \text { Jumlah nilai produk } & :- \\ \text { Jumlah nilai bahan baku } & : \text { Rp. } 45.000 .000\end{array}$

Sementara menurut data industri kecil tahun 2001 Kabupaten Garut (Dinas Perindustrian dan Perdagangan Kabupaten Garut) dikemukakan bahwa: 


$\begin{array}{ll}\text { Unit Usaha } & : 3 \text { unit } \\ \text { Tenaga Kerja } & : \text { 36 orang } \\ \text { Produksi } & : 1450 \text { potong } \\ \text { Nilai Investasi } & : \text { Rp. } 14.500 .000,- \\ \text { Nilai Produk } & : \text { Rp. } 45.000 .000,-\end{array}$

Berdasarkan urutan tahun di atas dapat dikatakan bahwa tahun 2001 dan 2002 usaha perbatikan di Garut berjumlah sangat sedikit dibandingkan dengan jenis usaha lainnya baik usaha formal maupun nonformal (rumahan).

Sedikit demi sedikit upaya pelebaran sayap pemasaran disertai dengan meningkatnya peminat batik memunculkan pengusaha-pengusaha baru pembuat batik Garutan. Hal ini tertuang dalam data jumlah unit usaha yang terkait dengan jenis industri kulit, tekstil, dan aneka industri tahun 2005. Tertera dalam data tersebut tentang adanya peningkatan jumlah nilai produksi yang tadinya (tahun 2001) berjumlah Rp. 45.000.000,- kemudian meningkat cukup tajam mencapai angka Rp. 388.000.000,- pada tahun 2005. Sebuah peningkatan yang cukup fantastis dalam kurun waktu selama kurang lebih 4 tahun. Saat ini jumlah tersebut semakin meningkat mengingat semakin banyaknya peminat batik Garutan. Beberapa di antara pengusaha batik yang dapat dikatakan sukses bertahan hingga saat ini adalah:

- RM 1 Jl. Papandayan No. 54 Garut Telp. (0262) 231028 Kontak : Ny. Sri Husaddah

- Batik Tulis Jl. Galunggung 11 Kota Kulon Garut Kota Telp.(0262) 233953 Kontak : Ny.

A. Suhanda

- Ratna Sari Jl. Gunung Payung 48 Telp.(0262) 233852 Kontak : Ny. Ai Maskanah Sholihin
Kurangnya minat generasi penerus pada usaha batik tulis, yang diperparah ketidaktersediaannya bahan baku dan permodalan, juga disebabkan lemahnya strategi pemasaran, yang juga mengakibatkan terjadinya kelangkaan. Padahal, katanya, pangsa pasar komoditas tersebut, sangat luas karena umumnya digunakan untuk kain sinjang (kebaya), dan pemenuhan kebutuhan sandang lainnya, dengan motif yang mencerminkan kearifan lokal sosial budaya, falsafah hidup serta adat-istiadat warga Sunda. Sehingga beragam perwujudan batik tulis Garutan, secara visual tergambar melalui motif dan corak warnanya, antara lain berbentuk geometrik sebagai ciri khas ragam hiasnya.

Menurut HR. Ruhiat, Kepala Dinas Perindustrian Perdagangan Koperasi dan UKM Garut, saat ini jumlah produksi batik Garut hanya terkonsentrasi di kawasan perkotaan, dengan rata-rata kapasitas produksi setiap tahun sebanyak 1.296 potong. Sementara kondisi industri batik tulis Garutan sekarang, hanya tersisa tiga unit usaha yang menyerap kurang dari 100 orang tenaga kerja. Dari ketiga industri tersebut, menurut catatan di Kota Garut, saat ini, hanya tinggal satu yang tetap berproduksi yaitu usaha yang dijalankan oleh Ibu Hajjah Uba Husaodah. Perusahaan tersebut berdiri sejak tahun 1979 dan kini memiliki tenaga perajin sebanyak 45 orang. Sebagian dari jumlah di atas, yakni sekitar 15 orang bekerja langsung di workshop, sedangkan sisanya tersebar di beberapa tempat seperti di Ciledug, Tarogong dan Bentar sebagai pegawai 
borongan. ${ }^{6}$ Investasi yang tertanam sekitar Rp. 30 juta, namun nilai produksinya setiap tahun rata-rata sebesar Rp. 388 juta berwujud produksi sandang, sinjang, kain bahan dan lain sebagainya.

Segmen pasar yang dibidik, antara lain Jakarta, Bandung serta Bali, termasuk kalangan wisatawan Nusantara dan manca negara, yang langsung menyempatkan berbelanja ke sentra industri batik tulis Garutan tersebut. Mereka rata-rata menggemari motif -motif lama seperti Bulu Hayam, Merak Ngibing dan Sido Mukti. Sementara di dalam wilayah Kecamatan Garut Kota sendiri, seluruh pegawai negeri sipil dan siswa juga mulai diwajibkan mengenakan busana batik. Alhasil batik Garutan tidak hanya semarak di luar tetapi juga di dalam wilayah Garut itu sendiri.

Melanie, seorang asisten pengelola perusahaan batik tulis garutan "RM", mengatakan, pemakaian baik Garutan untuk seragam pegawai pemerintah daerah sangat membantu dalam keberlanjutan usaha batik Garutan. Meskipun yang paling banyak digunakan adalah batik Garutan cap, batik Garutan tulis tidak kehilangan pasarnya.

Meski motif lama masih banyak digemari, namun terlihat selalu ada upaya kreatif pengusaha batik tulis Garut untuk memodifikasi motif lama agar lebih menarik calon pelanggan/pembeli. Dengan kata lain, modifikasi motif batik tulis Garut menjadi semakin penting artinya. Dan,

\footnotetext{
6 Batik Tulis Tradisional Sunda "Garutan", dalam http://a-koesmiadi.blog. friendster.com/2007/12/batik-sunda/feed/
}

hal ini dibenarkan oleh Tan Han Goen. Menurut Tan Han Goen, desainer asal Surabaya, saat ini banyak diproduksi batik dengan motif dan warna yang jauh dari kesan tua. "Tinggal cara memilih dan mendesain kain tersebut," kata desainer yang beberapa kali mendapatkan sertifikat dari Museum Rekor Indonesia (Muri) atas karyakaryanya tersebut.

Bahkan, menurut dia, kain batik tak harus selalu dipadupadankan dengan kebaya.'Hanya menggunakan kain serta selendangnya saja sudah bisa dijadikan busana," jelasnya. Caranya pun cukup mudah. Cukup dengan bantuan jarum pentul dan jahitan yang sifatnya tidak permanen, kain-kain batik itu bisa disulap menjadi busana yang modis. ${ }^{7}$

Tidak hanya busana, sudah banyak beredar di galeri-galeri batik tulis Garut yang menawarkan kain motif batik Garut (sebagian besar cetak) untuk berbagai keperluan rumah tangga, seperti sprey, gordeyn, sarung bantal dan guling, taplak, dan lain-lain.

Alih fungsi kain motif batik Garut yang sudah banyak beredar saat ini tentu disesuaikan dengan adanya penambahan beberapa aplikasi tambahan untuk mempercantik dan menguatkan fungsi tersebut. Kebaya, menurut Elistian $^{8}$, selama menggunakan batik motif yang tidak dipadu padan dengan

7 "Batik Tak Harus dengan Kebaya", dalam http://batiksastro.wordpress.com/2005/ 12/03/ batik-tak-harus-dengan-kebaya/ tanggal 3 Desember 2005.

8 "Batik Motif Natural Komunikasikan Eksotisme Alam", dalam http://batiksastro. wordpress.com/2005/10/02/batik-motif-naturalkomunikasikan-eksotisme-alam/tanggal 2 Nopember 2005 
aplikasi bordir bunga dan sebagian payet akan memberikan kesan kaku. Oleh karena itu untuk bisa menampilkan keluwesan pada si pemakai, Elistian memberi aplikasi bordir dan payet pada kebaya setelan batik. Begitu juga dengan selendangnya. Dengan strategi pemasaran demikian, para pengusaha batik Garut berharap untuk dapat lebih merebut perhatian peminat batik tidak hanya di daerah Garut saja melainkan juga dalam lingkup nasional maupun internasional.

Untuk menuju lingkup internasional tentu dibutuhkan berbagai sarana promosi seperti fashion show, pameran, ataupun lokakarya. Selain itu, dunia maya juga dapat menjadi salah satu sarana promosi yang cukup ampuh dalam menembus pasar internasional. Dan, beberapa galeri batik Garutan telah melakukan hal itu. Belum lagi ditambah dengan situs-situs dan blog yang dibina oleh instansi terkait dan organisasi swasta, ataupun perorangan yang turut mempromosikan batik Garut sebagai salah satu aset budaya dan ekonomi Kabupaten Garut.

Pasar Asia dan Afrika juga seakan terbuka lebar bagi prospek batik Garutan. Hal ini ditandai dengan adanya permintaan sekitar 500 potong batik tulis Garut saat perayaan 50 Tahun Konferensi Asia Afrika beberapa tahun lalu di Bandung walaupun sempat membuat cemas Budiman (Kepala Dinas Perdagangan Kabupaten Garut saat itu). Order yang besar dalam waktu yang singkat membutuhkan tenaga kerja dalam jumlah besar, padahal pada saat itu jumlah perajin batik tulis Garut yang tersisa hanya berjumlah 4 kelompok, namun dengan prospek yang cerah tidak menutup kemungkinan akan banyak produsen batik Garut. Apalagi dengan harga yang dipasarkan saat ini cukup menggiurkan bagi produsen. Saat ini harga batik tulis Garutan bervariasi dari mulai 50 ribu hingga 300 ribu rupiah per meter, bergantung kualitas dari batik. Dengan harga tersebut setidaknya dapat menutupi biaya produksi batik tulis Garutan yang saat ini mencapai jumlah Rp. 450.000,dalam sekali proses produksi. Belum lagi dengan upah kerja dan biaya transportasi/pemasaran. Pasar batik Garutan ini kini telah mulai menembus pasar internasional, seperti Singapura dan Malaysia.

\section{PENUTUP}

Mencermati proses perjuangan pengusulan batik ke UNESCO dapat dikatakan bahwa sebenarnya dengan penelitian terhadap kain-kain batik dapat diketahui beberapa data-data penting. Data-data ini dapat dipakai untuk memperkuat fakta-fakta sejarah. Kekuatan data dari batik adalah terletak pada pola, motif, dan jenis-jenis hiasan yang diterapkan pada kain-kain batik tersebut. Batik betul-betul merupakan gambaran tentang alam sekitar, perkembangan pemikiran, juga filosofi kehidupan yang ada saat itu yang mampu diungkapkan oleh para pembatik melalui karyanya. Membatik diperlukan kemampuan dan penguasaan teknik membatik juga konsepkonsep dan pengetahuan motif-motif ornamentiknya. Hal ini untuk menjaga agar nilai perlambangan yang ada pada tiap motif atau desain batik juga warna yang dipakai tidak hilang.

Membatik, yang pada dasarnya adalah suatu perjuangan proses kreatif melalui sebuah ungkapan berupa 
gambar pada media kain, ternyata sarat dengan makna. Makna ini dibangun sebagai sebuah hasil simbolisasi, pengharapan, tetapi tidak menutup kemungkinan juga ungkapan nyata dari realitas yang terjadi pada diri dan lingkungan hidup si pembatik. Karena itulah pembatik membuat kain batik atas beberapa alasan, seperti membatik atas pesanan dan muatan ataupun membatik karena alasan perekonomian. Alasan ini merupakan sebuah alasan umum yang diucapkan oleh pembatik dari berbagai daerah, termasuk pembatik motif Garutan di Kabupaten Garut.

Istilah batik Garut meski bukan merupakan produk asli garutan ansicht - tetapi sebagai bagian dari proses panjang penyebaran motif batik di pulau Jawa - namun patut dibanggakan karena hasil kombinasi motif dan warna sudah diakui dan mencerminkan motif dan warna khas yang membedakan dengan motif dan warna dengan batik daerah lain.

Kekayaan budaya Kabupaten Garut bukan hanya untuk dibanggakan semata melainkan dapat menjadi salah satu aset ekonomi perorangan, kelompok, yang kemudian dapat memberikan nilai tambah bagi Pendapatan Asli Daerah (PAD) Kabupaten Garut. Dan, pemerintah Kabupaten Garut memberikan respon positif dalam bentuk sosialisasi aset budaya mereka, baik di dalam wilayah Kabupaten Garut itu sendiri, ataupun ke daerah lain dalam tingkat nasional maupun internasional. Hal demikian ternyata membuahkan hasil dan kini semakin banyaknya permintaan kain-kain bernuansa motif batik Garutan baik dari tingkat nasional maupun internasional.
Sosialisasi juga didukung oleh inovasi dalam bentuk penambahan motif batik tidak hanya pada pakaian semata tetapi juga pada peralatan rumah tangga yang terbuat dari kain seperti gordeyn, taplak, sprei, dan lainlain. Alhasil, strategi pemasaran yang demikian secara tidak langsung mendongkrak angka penjualan. Belum lagi ditambah dengan promosi di dunia maya yang mampu menyebarkan informasi batik Garutan ke segala penjuru dunia.

Keberhasilan strategi pemasaran batik Garutan saat ini rupanya memiliki lubang-lubang kelemahan yang meskipun sedikit namun cukup vital, yaitu proses regenerasi pembatik. Hingga saat ini, terutama batik tulis Garutan, masih sangat sedikit jumlahnya. Berbeda dengan pembatik cap yang sedikit demi sedikit mulai banyak peminatnya. Gengsi masih menjadi kendala utama dari para generasi muda untuk bekerja sebagai pembatik tulis Garutan. Apalagi pekerjaan sebagai pembatik dianggap sebagai pekerjaan generasi tua.

Menginjak pada akhir tulisan ini dapat dikatakan bahwa ada nilai plus minus dalam strategi pemasaran batik tulis Garutan ini. Dan, pemerintah daerah Kabupaten Garut khususnya harus menanggapi secara serius agar tidak menjadi bom waktu yang membuat batik Garutan yang menjadi salah satu kebanggaan masyarakat Garut sedikit demi sedikit mulai mengalami kepunahan.

\section{DAFTAR PUSTAKA}

Affendi, Yusuf. 2000.

"Seni Kriya Batik dalam Tradisi

Baru Menghadapi Arus Budaya 
Global", dalam Jurnal Seni Rupa dan Desain Volume 1,1, Agustus 2000, Bandung: Pusat Penelitian dan Pengembangan Masyarakat (P3M) Sekolah Tinggi Seni Rupa dan Desain Indonesia (STISI) Bandung.

Djomena, Nian. 1990.

Ungkapan Sehelai Batik. Jakarta: Jambatan.

Dwiyanto, Djoko dan DS. Nugrahani, DS. 2000 .

"Perubahan Konsep Gender dalam Seni Batik Tradisional Pedalaman dan Pesisiran", dalam hasil penelitian Proyek Pengkajian dan Penelitian Ilmu Terapan, Ditbinlitabmas, Ditjen Dikti Tanggal 15 Mei.

Fakih, Mansour, 1997.

Analisis Gender dan Transformasi Sosial, Yogyakarta: Pustaka Pelajar Offset.

Fox, James J. 1977.

"The Textile Tradition of Pote, Ndao and Savu", in M. Kahlenb Berg (ed.), Textile Tradition of Indonesia, Los Angeles: Los Angeles Country Museum of Art, pp. 97-104.

Fraser-Lu, Sylvia, 1986.

Indonesian Batik: Processes, Patterns and Places, Singapore: Oxford University Press.

H Loupias. Henry, 2004

"Batik Tulis Tradisional Sunda "Garutan", dalam Pikiran Rakyat, Minggu, 28 Maret 2004 hal. 21.

Hamzuri. 1989.

Batik Klasik. Jakarta: Jambatan
Hayati, Amelia, 2007.

"Pengaruh Sosial, Ekonomi, dan Budaya terhadap Kewirausahaan Batik Garutan", Makalah dalam Regional Asia-Pasific Workshop Entrepreneurship Development tanggal 29-30 November, Bali, Indonesia

Johnston, M \& Glen K. 1967.

Design on Fabric. New York: Van Nostrand Reinhold Company.

Oetomo, Dede. 2005. "Penelitian Kualitatif: Aliran dan Tema", dalam Bagong Suyanto dan Sutinah (ed), Metode Penelitian Sosial: Berbagai Alternatif Pendekatan, Jakarta: Kencana, 2005.

Nugroho, Rony Ariyanto, 2009,

"Garut Sudah Patenkan 31 Motif Batik Khas Daerah", dalam KOMPAS Jumat, 2 Oktober.

Riswinarno, tt,

"Di Wajahmu Tersurat Fakta: Menelisik Informasi Masa Lampau melalui Kain Batik", makalah.

Rizali, Nanang, dkk 2003.

"Batik Garut Kajian Bentuk dan Warna", dalam Jurnal Seni Rupa dan Desain Volume 3, 6, Agustus.

Sairin, Sjafri. 2002.

Perubahan Sosial Masyarakat

Indonesia Perspektif

Antropologi, Yogyakarta:

Pustaka Pelajar.

Schoeffel, Penelope, 1995.

"Craft, Prestige Goods and Woman's Roles in the Pacific 
Islands", in Loma Kaino (ed)., The Necessity of Craft: Development and Woman's Craft Practices in the Asia -Pacific Region, Nedland, Western Australia: University of Western Australia Press, pp. 1-23.

Storey, Joyce. 1992.

Textile Printing. London: Thames R Hudson.

Susanto, Sewan S.K. 1973.

Seni Kerajinan Batik Indonesia. Yogyakarta: Balai Penelitian Batik dan Kerajinan.
Widiyantie, Tri, 2007.

"Menelusuri Asal Usul Pembuatan Batik Pakaian Khas Keraton yang Menjadi Pakaian Rakyat", dalam Galamedia Minggu, tanggal 18 Maret.

"Bertahan di Tengah Pesatnya Batik 'Printing' Gaya dengan Batik Tulis Garutan", dalam Pikiran Rakyat, Selasa 16 Januari 2007 halaman 21 